\title{
Waste Heat Recovery from Exhaust Gas and Cooling Water as Water Heater on Domestic System of a Cruise Ship 48 meters
}

\begin{abstract}
Sutopo Purwono Fitri ${ }^{1}$, Agoes Santoso ${ }^{2}$, Nizar Febri Anggriawan ${ }^{3}$
(Received:04 February 2019 / Revised: 11 March 2019/ Accepted: 26 March 2019)

Abstract-cruise ship is a ship used for recreational and entertainment purposes. As a means of vacation and entertainment, the design of this transportation requires more attention. The design of the ship itself must be able to make it comfortable for the passengers. One of them, to increase comfort for cruise ship passengers is by adding heating water to the domestic system. Will need a large amount of electrical energy if using an electric heater. While in the engine room there is exhaust heat that can be utilized. The purpose of this research is to plan the utilization of waste heat contained in the exhaust gas and cooling water system (high temperature) as a water heater on the domestic system. The method used is the analysis of calculations. From the results of the calculation analysis, it was found that the hot water requirements of this ship were 3409 liters/day and needed a heat $167.12 \mathrm{~kJ} / \mathrm{s}$ to increase the water temperature from $25^{\circ} \mathrm{C}$ to $66^{\circ} \mathrm{C}$. From the calculation results, the $50 \%$ load engine has a heat $469 \mathrm{~kJ} / \mathrm{s}, 75 \%$ load engine has a heat $645 \mathrm{~kJ} / \mathrm{s}, 80 \%$ load engine has a heat $729 \mathrm{~kJ} / \mathrm{s}, 100 \%$ load engine has a heat $781 \mathrm{~kJ} / \mathrm{s}$, while in cooling water system (high temperature) has a heat $252 \mathrm{~kJ} / \mathrm{s}$. Tank insulation using glass wool with a thickness of $610 \mathrm{~mm}$. While the insulation on the pipe uses glass wool with thickness $50 \mathrm{~mm}$. By replacing the electric water heater by utilizing heat waste can minimize the cost up to Rp.245,211.833/day or Rp.7,356,355.008/month.
\end{abstract}

Keywords—domestic system, waste heat recovery, water heater.

\section{INTRODUCTION}

$\mathrm{T}$ he cruise ship is a ship that is used specifically for recreational and entertainment purposes. As a means of vacation and entertainment, the design of this transportation requires more attention. The design of the ship itself must be able to make it comfortable for the passengers. One of them, to increase comfort for cruise ship passengers is by adding heating water to the domestic system. In obtaining hot water on domestic systems on ships there are several ways by using electricity, gas, and solar power.

Electricity consumption for the operation of electric water heaters on ships requires a large amount of energy and costs are expensive. Whereas if using solar power the cost that must be spent is far more expensive than using an electric water heater.

While in the engine room there is wasted heat formed from the engine and other components. At present day there are many technologies that utilize waste heat energy to be used as the turbocharger, refrigeration, and desalination. So to obtain hot water without using electric water heater and solar power, it is a planned system that exploits waste heat for a domestic system in a ship. By utilizing this waste heat indirectly we can reduce the need for electricity usage [1-4].

Sutopo Purwono Fitri, Department of Marine Engineering, Institut Teknologi Sepuluh Nopember, Surabaya 60111, Indonesia, Email: spurwono@yahoo.com

Agoes Santoso, Department of Marine Engineering, Institut Teknologi Sepuluh Nopember, Surabaya 60111, Indonesia, Email: agoes@its.ac.id

Nizar Febri Anggriawan, Department of Marine Engineering, Institut Teknologi Sepuluh Nopember, Surabaya 60111, Indonesia, Email: nizar.febri@gmail.com

\section{METHOD}

\section{A. Waste Heat}

Waste heat recovery is one example of energy savings which aims to improve the efficiency of fuel use. In diesel engines, there are 3 main heat sources that can be utilized, including exhaust heat generated from jacket water, exhaust gas, and also from cooling water [1-4]. Factors affecting Waste Heat Recovery as follows:

1) Heat Quantity

Heat quantity is the amount of heat energy contained in waste heat.

2) Waste Heat Temperature

Waste heat temperature is a factor that determines whether the temperature of the exhaust heat can be utilized.

3) Waste Stream Composition

Waste stream composition is a chemical content found in waste heat, which can affect the material and recovery process.

4) Minimum allowable temperature limit

\section{B. Heat Transfer}

Heat transfer is the process of transferring heat or heat caused by temperature differences. Where heat will move from high temperatures to lower temperatures. This transfer process will continue until there is a temperature balance in both media [5-10]. The process of heat transfer can be divided into three, namely as follows:

1) Conduction

Conduction heat transfer is heat transfer that occurs on a solid medium, or on a silent fluid. Conduction occurs due to temperature differences between one surface and another on the media.

2) Convection 
Convection is the transfer of heat that occurs to a silent fluid to a fluid that flows, and vice versa which temperature differences without the need for occurs due to differences in temperature.

3) Radiation

Radiation heat transfer can be said to be the process of transferring heat from one medium to another due to

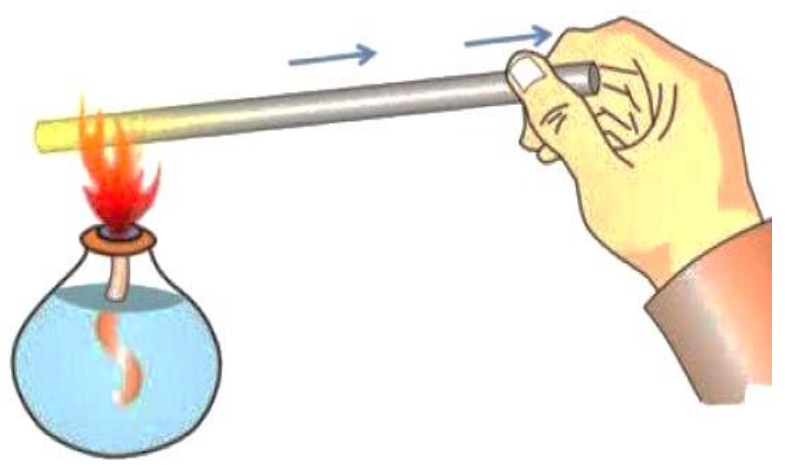

Figure. 1. Conduction

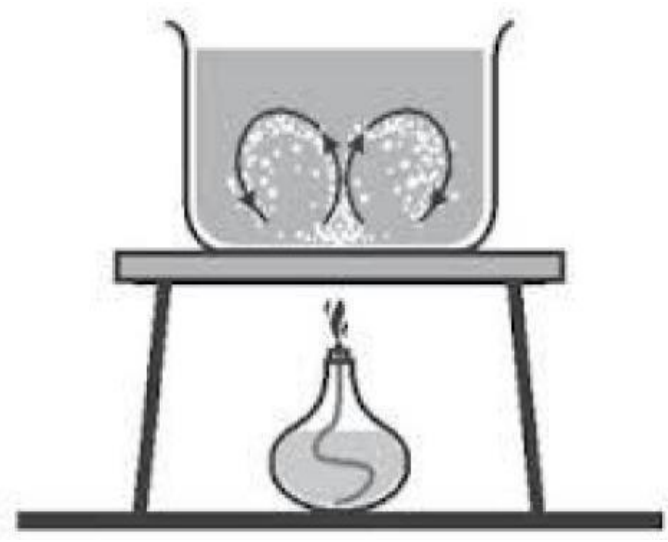

Figure. 2. Convection
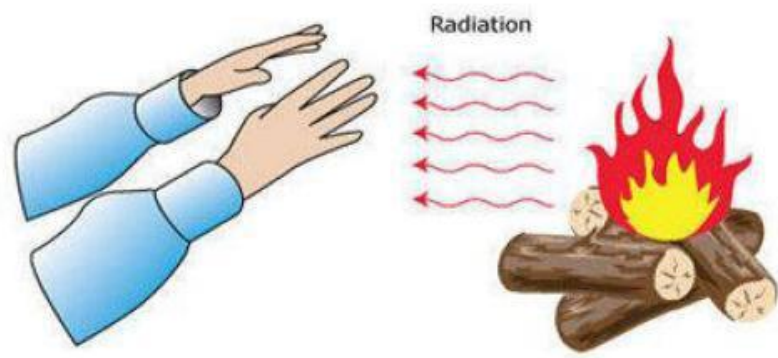

Figure. 3. Radiation

\section{Heat Exchanger}

The heat exchanger is a device used to exchange heat between two fluids, both of which have different temperatures. In general, heat exchangers used in various applications, for example, are used as heating and air conditioning systems in homes, used as chemical processes and as power plants [11].

Heat transfer in a heat exchanger usually involves two heat transfer processes, namely convection in each liquid and conduction through a wall separating two liquids [12]. The heat transfer rate between two fluids in a heat exchanger depends on the amount of temperature difference that varies along the heat exchanger. The types of heat exchangers vary greatly and can be classified as follows [13-15]:

1) Number of streams

Most processes of heat transfer between fluids involve only two different types of fluid. Such as water with water, steam with water, steam with sea water, and so forth

2) Transfer Process

According to the transfer process, the heat exchanger is divided into two, namely direct contact and indirect contact. The definition of direct contact itself is the transfer of heat 
transferred between the cold fluid and hot fluid through direct contact, between these fluids there is no dividing wall. While the understanding of indirect contact heat transfer process between these

3) Construction geometry

The geometry of construction for the heat exchanger is divided into three types, namely tubular, plate, and extended surfaces. two fluids is limited by a dividing wall. Hot fluids and cold fluids flow simultaneously while heat energy is transferred through the separation wall.

4) Heat transfer mechanism

Basically, the heat transfer mechanism is used to transfer heat energy from the fluid that is on one side of the heat exchanger to the separation wall. There are several types of heat transfer mechanisms, namely:

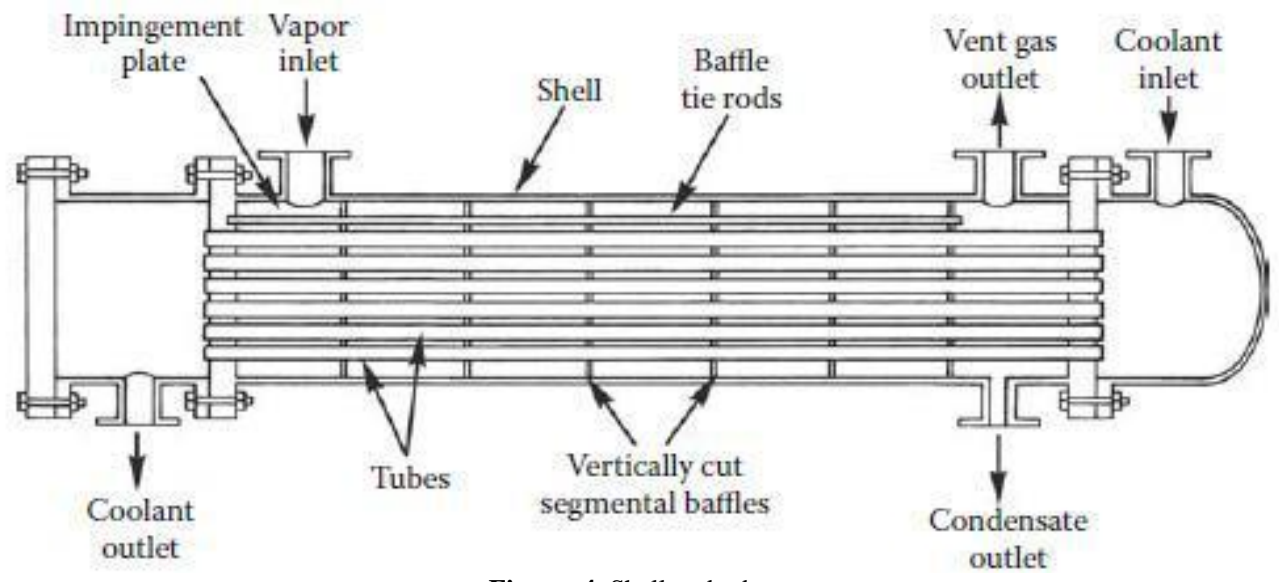

Figure. 4. Shell and tube

1. Single phase convection on both sides.

2. Single phase convection on one side, the other two-phase convection on phase.

3. Two-phase convection on both sides.

5) Flow settings

Based on the flow, heat exchangers can be divided into three types, namely Parallel flow, Counterflow, and Crossflow. The definition of parallel flow is where working fluids in the heat exchanger flow parallel and have the same flow direction between fluid one with the other fluid. While the notion of counterflow where the fluids flowing in the heat exchanger has the direction of the flow opposite between one fluid with another fluid. Crossflow two fluids flowing in this type of heat exchanger have perpendicular or crossing directions.

6) Compact surface

The next classification of heat exchangers is based on the area of the contact area between inter-fluid heat transfer. The parameters used in this classification are the large unit surface area of contact in each heat exchanger volume. The more surface area of the contact area of heat transfer per unit volume, the greater the heat transfer efficiency obtained. But this must also pay attention to the type of working fluid used. The greater the particle content in the fluid, the lower the need for the surface area of the heat transfer contact area in the heat exchanger.

\section{Selection of Heat Exchanger}

There are many criteria in choosing a heat exchanger, but the main criteria are the type of fluid that must be handled, operating pressure and temperature, heat energy, and cost. While the fluid involved in heat transfer can be categorized into temperature, pressure, phase, physical properties, toxicity, corrosivity, and fouling tendency. The operating conditions for heat exchangers vary in a very wide range, and a broad spectrum of requests is imposed for their design and performance. All of this must be considered when assessing the type of unit to be used. When choosing a heat exchanger the following points must be considered [14].

1. Construction material

2. Pressure and temperature during operation

3. Flow rate

4. Flow arrays

5. Parameters for the effectiveness of heat and pressure drop

6. Fouling

7. Type and phase of the fluid

8. Maintenance, inspection, cleaning, and repair

9. Overall costs

10. Fabrication techniques

11. Applications

\section{E. Calculation of Heat Exchanger}

The research method is based on the following calculations $[11,12]$ :

1) Heat duty

To find out the amount of heat that can be transferred from hot fluids to cold fluids in a heat exchanger, calculations are carried out based on the following equation.

$\mathrm{Q}=\mathrm{m}_{\mathrm{h}} . \mathrm{C}_{\mathrm{p}}$.

2) LMTD (Log Mean Temperature Difference)

To calculate the average temperature of a fluid flowing in a heat exchanger can be calculated by the following equation.

$\mathrm{LMTD}=(\mathrm{th}-\mathrm{tc}) /(\ln \mathrm{th} / \mathrm{tc})$

3) Caloric temperature 
Is the temperature that corresponds to each stream or stream. Caloric temperature can be calculated by the following equation. For hot fluids

$\mathrm{Tc}=\mathrm{T} 2+\mathrm{Fc}(\mathrm{T} 1-\mathrm{T} 2)$

For cold fluids

$\mathrm{Tc}=\mathrm{t} 1+\mathrm{Fc}(\mathrm{t} 2-\mathrm{t} 1)$

4) Flow area

Flow area is the area passed by each fluid and can be calculated by the following equation.

For hot fluids

as $=($ IDs.CB $) /(144 \mathrm{Pt})$

For cold fluids

at $=(\mathrm{Nt} . \mathrm{At}) /(144 \mathrm{n})$

5) Mass velocity

That is the mass velocity of each fluid, which can be calculated by the following equation.

For hot fluids

$\mathrm{Gs}=\mathrm{ms} / \mathrm{as}$

For cold fluids

$\mathrm{Gt}=\mathrm{mt} / \mathrm{at}$

6) Reynold number

For hot fluids

Res $=($ De.GS $) / \mu$

For cold fluids

Ret $=($ IDt.Gt $) / \mu$

7) Dimension factor for a heat exchanger $(\mathrm{JH})$

To determine the dimensional factor can be seen in the diagram.

8) Prandtl Number (Pr)

Prandtl numbers can be calculated by the following equation.

$\operatorname{Pr}=(\mathrm{Cp} . \mathrm{M}) / \mathrm{K}$

9) Heat transfer coefficient

The heat transfer coefficient can be calculated using the following equation.

hi $/ \varnothing \mathrm{t}=\partial \mathrm{H} \times \mathrm{K} / \mathrm{IDt} \operatorname{Pr} 1 / 3$

10) The temperature on the tube wall

The temperature on the tube wall can be calculated using the following equation.

$\mathrm{tw}=\mathrm{tc}+\left(\mathrm{h} /{ }_{\varphi} \mathrm{S}\right) /\left(\right.$ hio $\left./{ }_{\varphi} \mathrm{t}+\mathrm{ho} /{ }_{\varphi} \mathrm{S}\right)(\mathrm{Tc}-\mathrm{tc})$

hio $/ \varnothing \mathrm{t}=($ hio $/ \emptyset \mathrm{t} \mathrm{x}$ IDt $) / \emptyset \mathrm{tODt}$

11)Fluid viscosity ratio

The viscosity ratio of the fluid can be calculated using the following equation.

On the shell side and tube side

${ }_{\varphi} \mathrm{s}=\mu /(\mu \mathrm{w})$

12)The corrected heat transfer coefficient

The corrected heat transfer coefficient can be calculated using the following equation.

On the tube side

$\mathrm{hi}=\varnothing \mathrm{t} \times \partial \mathrm{H} \times \mathrm{K} / \mathrm{IDt} \operatorname{Pr} 1 / 3$

On the tube wall

hio $=\varnothing \mathrm{t}+(\mathrm{hi} / \varnothing \mathrm{t} \times \mathrm{ODt}) / \mathrm{ODt}$

On the shell side wal

ho $=\varnothing \mathrm{s} \times \partial \mathrm{H} \times \mathrm{K} / \mathrm{De} \operatorname{Pr} 1 / 3$

13) Clean overall coefficient

The clean overall coefficient is that the heat transfer conductors in the heat exchanger are clean, clean overalls can be calculated using the following equation.

$$
\mathrm{Ud}=\mathrm{Qt} / \text { (Nt.La ". LMTD) }
$$

14)Fouling Factor / dirty factor

Fouling factors are obstacles to heat transfer due to the presence of deposits in the heat exchanger. Fouling factors are influenced by several things including fluid type, temperature, tube material, and flow velocity during operation.

$$
\mathrm{Rd}=(\mathrm{Uc}-\mathrm{Ud}) /(\mathrm{Uc} . \mathrm{Ud})
$$

15) Pressure drop

Pressure drop is the maximum reduction in pressure allowed in a heat exchanger when a fluid passes through it. The pressure drop will be greater if the value of the fouling factor increases, the pressure drop can be calculated using the following equation. $\Delta \mathrm{Ps}=\left(\mathrm{f} . \mathrm{Gs}^{\wedge} 2(\mathrm{~N}+1)\right) /(5.22 \mathrm{x} \llbracket 10 \rrbracket \wedge 10 . \mathrm{Dc} . \mathrm{SG} \emptyset \mathrm{s}) \ldots . .(21)$

\section{F. Domestic System}

Domestic system is a system that aims to serve the needs of fresh water and sea water for the passengers of the ship during the voyage. Domestic systems are used in some rooms for example:

1. Bathroom

2. Washing place

3. Kitchen

In the domestic system is divided into 2 systems, namely the fresh water supply system, and seawater supply system, where the components of the system are as follows:

1. Sea chest is a place for the entry of seawater for the needs of a seawater supply system on board.

2. Seawater pump functions to move sea water from sea chest to hydrophore.

3. Seawater hydrophore is a place to store seawater before being distributed for domestic purposes on a ship.

4. Freshwater tanks are a place to store fresh water on a ship.

5. Freshwater pumps a tool used to move fresh water from the fresh water tank to hydrophore.

6. Freshwater hydrophore is a place to store fresh water before being distributed for domestic system needs.

\section{RESULT AND DISCUSSION}

\section{A. Data collection}

Data collection for this research is the main dimension, the specifications of the engine on the 48meter cruise ship, the need for fresh water for the domestic system on a 48-meter cruise ship.

1) Main Dimension

$\begin{array}{ll}\text { LOA } & : 48,34 \mathrm{~m} \\ \text { LWL } & : 43,34 \mathrm{~m} \\ \text { LPP } & : 42,59 \mathrm{~m} \\ \text { BREADTH } & : 7,80 \mathrm{~m} \\ \text { HEIGH } & : 15,11 \mathrm{~m} \\ \text { DRAFT } & : 1,80 \mathrm{~m} \\ \text { VS } & : 16 \text { Knot }\end{array}$

2) Machinery

Main Marine Engine : 3 x 1340 KW YANMAR 12

AYM-WGT. Table 1 is data for load main engine. 
TABLE. 1.

FLOWRATE AND TEMPERATURE EXHAUST GAS

\begin{tabular}{cccc}
\hline $\begin{array}{c}\text { Load } \\
(\boldsymbol{\%})\end{array}$ & $\begin{array}{c}\text { Temperature } \\
\left({ }^{\circ} \mathbf{C}\right)\end{array}$ & $\begin{array}{c}\text { Flow rate } \\
(\mathbf{k g} / \mathbf{s})\end{array}$ & $\begin{array}{c}\mathbf{Q} \\
(\mathbf{k J} / \mathbf{s})\end{array}$ \\
\hline 100 & 323 & 2.3 & 781 \\
80 & 330 & 2.1 & 729 \\
75 & 340 & 1.8 & 645 \\
50 & 358 & 1.2 & 469 \\
\hline
\end{tabular}

4) Cooling Water System (HT)

Based on data from the project guide, it is known that the energy that can be used in the cooling water system (HT) is $252 \mathrm{~kW}$ or $252 \mathrm{~kJ} / \mathrm{s}$

4) Amount of fresh water

Data for ship fresh water tank are:

- Freshwater tank portside: 5000 liters

- Freshwater tank starboard: 5000 liters

From the data above, it can be seen that the total volume of 10000 liters of fresh water $60-85 \%$ will become domestic liquid waste. $75 \%$ of domestic liquid waste is gray water.

Then the statement can be used as a reference for freshwater needs where:
Domestic waste volume $=85 \%$ x 10000 liters

$$
\begin{aligned}
& =8500 \text { liters } \\
& =75 \% \text { x } 8500 \text { liters } \\
& =6880 \text { liters }
\end{aligned}
$$

So that the gray water (freshwater) needed by the ship for per day (for 45 hours or 2 days) is 6880 liters divided by 2 . So that freshwater needs are also worth the same, namely 3440 liters per day.

As for the temperature of hot water needed can be seen at MSN 1884 Merchant Shipping Notice (M). So that the mass of warm water needed is as follows:

$$
\begin{aligned}
\text { Hot water mass } & =\text { vol. of water } \mathrm{x} \text { density }\left(66^{0} \mathrm{C}\right) \\
\text { Hot water mass } & =3440 \times 0.991 \mathrm{~kg} / 1 \\
\text { Hot water mass } & =3409 \mathrm{~kg} / \text { day } \\
& =142 \mathrm{~kg} / \mathrm{h}
\end{aligned}
$$

\section{B. Heat Exchanger Calculations Result}

Table 2 until table 4 are calculation result for a heat exchanger in the domestic system.

TABLE. 2.

HEAT EXChANGER DESIGN Data

\begin{tabular}{lcccccc}
\hline \multicolumn{1}{c}{ Parameter } & \multicolumn{5}{c}{ Shell } & \multicolumn{3}{c}{ Tube } \\
\cline { 2 - 7 } & Notation & Unit & Dimension & Notation & Unit & Dimension \\
\hline Outside diameter & OD & inch & 15.25 & OD & & \\
Inside diameter & ID & inch & & ID & 1 & \\
Number of baffles & $\mathrm{N}$ & unit & 4 & & & \\
Number of passes & $\mathrm{n}$ & unit & 1 & & & Water \\
Type of fluid & & & Gas & & & \\
BWG & & & 13 & & inch & 1.25 \\
Distance between tube & & & & C & ft & 8 \\
Tube length & & & & N & unit & 68 \\
Number of tubes & & & & Nt & inch & 3.05 \\
Distance between baffle & & & & B & & \\
\end{tabular}

TABLE. 3 .

HEAT EXCHANGER CALCULATION

\begin{tabular}{lccc}
\hline \multicolumn{1}{c}{ Parameter } & Unit & Shell & Tube \\
\hline Heat balance & $\mathrm{BTU} / \mathrm{hr}$ & 22310 & 22310 \\
LMTD & $\mathrm{F}$ & & 484.5 \\
Caloric temperature & $\mathrm{F}$ & 0.085 & \\
Flow area & $\mathrm{ft}^{2}$ & 12235.3 & 0.060 \\
Mass velocity & $\mathrm{lb} / \mathrm{hr}^{-\mathrm{ft}^{2}}$ & 14002 & 5250 \\
Reynold number & & 50 & 2883 \\
Heat transfer factor & & 0.8 & 7 \\
Specific heat & & 30 & 688.5 \\
Heat transfer coefficient & $\mathrm{BTU} / \mathrm{hr}_{\mathrm{fft}} \mathrm{ft}^{2} \mathrm{~F}$ & & 43.4 \\
Clean overall coefficient (Uc) & $\mathrm{BTU} / \mathrm{hr}_{\mathrm{ft}} \mathrm{F}$ & & 35 \\
Design overall coefficient (UD) & $\mathrm{BTU} / \mathrm{hr} . \mathrm{ft}^{2} \mathrm{~F}$ & & 0.005 \\
Fouling factor (Rf) & & 1.6 & - \\
Max fouling factor & & 2 & 3.4 \\
Pressure drop & $\mathrm{psi}$ & & 10 \\
Max pressure drop & $\mathrm{Psi}$ & & \\
\hline
\end{tabular}


TABLE. 4.

HEAT EXCHANGER OPERATING CONDITION

\begin{tabular}{lccccc}
\hline \multicolumn{1}{c}{ Parameter } & Unit & \multicolumn{2}{c}{ Shell } & \multicolumn{2}{c}{ Tube } \\
\cline { 3 - 6 } & & Notation & Dimension & Notation & Dimension \\
\hline Flowrate & $\mathrm{lb} / \mathrm{hr}$ & $\mathrm{W}$ & 1040 & $\mathrm{~W}$ & 315 \\
Inlet temperature & $\mathrm{F}$ & $\mathrm{T} 1$ & 676 & $\mathrm{t} 1$ & 77 \\
Outlet temperature & $\mathrm{F}$ & $\mathrm{T} 2$ & 583 & $\mathrm{t} 2$ & 151 \\
Temperature different & $\mathrm{F}$ & & 93 & 74 \\
Max pressure drop & $\mathrm{psi}$ & & 2 & & 10 \\
\hline
\end{tabular}

C. Tank Insulation

In determining the thickness of the insulation the author uses the Jimmy Kumana and Samir Khotari methods in the Predict Storage Tank Precisely
Heat Transfer paper. Table 5 until table 9 are calculation result in water tank and insulation.

TABLE. 5 .

TANK SPECIFICATION

\begin{tabular}{|c|c|c|}
\hline Fouling Coefficient Assumption & Value & Unit \\
\hline Drywall (hFd) & 700 & $\mathrm{BTU} / \mathrm{ft}^{2} \mathrm{~h} \mathrm{~F}$ \\
\hline Wet wall (hFw) & 550 & $\mathrm{BTU} / \mathrm{ft}^{2} \mathrm{~h} \mathrm{~F}$ \\
\hline Roof (hFr) & 700 & $\mathrm{BTU} / \mathrm{ft}^{2} \mathrm{~h} \mathrm{~F}$ \\
\hline Bootom $(\mathrm{hFb})$ & 550 & $\mathrm{BTU} / \mathrm{ft}^{2} \mathrm{~h} \mathrm{~F}$ \\
\hline Thermal conductivity & Value & Unit \\
\hline Galvanized steel (kM) & 24.5 & $\mathrm{BTU} / \mathrm{ft}^{2} \mathrm{~h} \mathrm{~F}$ \\
\hline Glasswool insulation (kI) & 0.029 & $\mathrm{BTU} / \mathrm{ft}^{2} \mathrm{~h} \mathrm{~F}$ \\
\hline Material thickness (tM) & 0.02 & $\mathrm{ft}$ \\
\hline Insulation thickness (tI) & 0.2 & $\mathrm{ft}$ \\
\hline Surface emissivity & \multicolumn{2}{|c|}{ Value } \\
\hline Wall and roof & \multicolumn{2}{|c|}{0.8} \\
\hline Temperature & Value & Unit \\
\hline Steam in a tank (TV) & 144 & $\mathrm{~F}$ \\
\hline Water in a tank (TL) & 151 & $\mathrm{~F}$ \\
\hline Environment (TA) & 95 & $\mathrm{~F}$ \\
\hline Size of tank & Value & Unit \\
\hline Diameter (D) & 1.96 & $\mathrm{ft}$ \\
\hline The height of tank (L) & 3.93 & $\mathrm{ft}$ \\
\hline The height of water (Lw) & 2.64 & $\mathrm{ft}$ \\
\hline Physical properties & Value (water) & Unit \\
\hline Density & 61.19 & $\mathrm{lb} / \mathrm{ft}^{3}$ \\
\hline Specific heat & 1 & $\mathrm{BTU} / \mathrm{ft}^{2}$ h F \\
\hline Viscosity & 2.733 & $\mathrm{lb} / \mathrm{ft} \mathrm{h}$ \\
\hline $\begin{array}{l}\text { Coefficient of volume metric } \\
\text { expansion }\end{array}$ & 0.00028 & $/ F$ \\
\hline Physical properties & Value (steam) & Unit \\
\hline Density & 0.062 & $\mathrm{lb} / \mathrm{ft}^{3}$ \\
\hline Specific heat & 0.234 & $\mathrm{BTU} / \mathrm{ft}^{2} \mathrm{~h} \mathrm{~F}$ \\
\hline Viscosity & 0.12 & $\mathrm{lb} / \mathrm{ft} \mathrm{h}$ \\
\hline $\begin{array}{l}\text { Coefficient of volume metric } \\
\text { expansion }\end{array}$ & 0.002 & $/ F$ \\
\hline
\end{tabular}


International Journal of Marine Engineering Innovation and Research, Vol. 3(3), Mar. 2019. 84-92 (pISSN: 2541-5972, eISSN: 2548-1479)

TABLE. 6.

AREA OF EACH WALL

\begin{tabular}{lc}
\multicolumn{2}{c}{ AREA OF EACH WALL } \\
\hline \multicolumn{1}{c}{ Wall } & Area $\left(\mathbf{f t}^{2}\right)$ \\
\hline Drywall $(A d)$ & 1.58 \\
Wet wall $(A w)$ & 38.25 \\
Roof $(A r)$ & 11.4 \\
Bottom $(A b)$ & 16.33 \\
Total & 67.56 \\
\hline
\end{tabular}

TABLE. 7.

TOTAL COEFFICIENT HEAT LOSS

\begin{tabular}{lcccc}
\hline Coefficient & Drywall & Wet wall & Roof & Bottom \\
\hline $\mathrm{hVw}$ & 0.3618 & - & - & - \\
$\mathrm{hLw}$ & - & 1.449 & - & - \\
$\mathrm{hVr}$ & - & - & 0.2035 & - \\
$\mathrm{hLb}$ & - & - & - & 17.66 \\
$\mathrm{hAr}$ & - & - & 9.18 & - \\
$\mathrm{hAw}$ & 955.6 & 955.6 & 955.6 & 955.6 \\
$\mathrm{hM}$ & 1225.5 & 1226.5 & 1227.5 & 1228.5 \\
$\mathrm{hI}$ & 0.1445 & 1.1445 & - & - \\
$\mathrm{hF}$ & 700 & 550 & 700 & 550 \\
$\mathrm{hR}$ & 0.964 & 1.054 & 0.964 & 1.054 \\
$\mathrm{l} / \mathrm{U}$ & 9.6875 & 7.4449 & 11.8358 & 7.023 \\
$\mathrm{U}$ & 0.1032 & 0.1343 & 0.0845 & 0.1424 \\
\hline
\end{tabular}

TABLE. 8.

TEMPERATURE CORRECTION OF EACH WALL

\begin{tabular}{lc}
\hline \multicolumn{1}{c}{ Wall } & Temperature $(\mathbf{F})$ \\
\hline Tws drywall & 100.05 \\
Tw drywall & 135.74 \\
Tws wet wall & 100.07 \\
Tw wet wall & 147.96 \\
Tws roof & 100.02 \\
Tw roof & 129.28 \\
Tws bottom & 100.01 \\
Tw bottom & 148.43 \\
\hline
\end{tabular}

TABLE. 9.

HEAT LOSS THAT OCCURS ON THE TANK

\begin{tabular}{lccc}
\hline \multicolumn{1}{c}{ Wall } & $\mathbf{U}\left(\mathbf{B t u} / \mathbf{f t}^{2} \mathbf{h} \mathbf{F}\right)$ & $\mathbf{A}\left(\mathbf{f t}^{2}\right)$ & $\mathbf{q}(\mathbf{B t u} / \mathbf{h})$ \\
\hline Dry wall & 0.1032 & 1.58 & 10.21 \\
Wett wall & 0.1343 & 38.25 & 287.67 \\
Roof & 0.0845 & 11.4 & 47.2 \\
Bottom & 0.1424 & 16.33 & 118.6 \\
Total & & 67.56 & 463.68 \\
\hline
\end{tabular}


1) Heat loss (24 hours)

$$
\begin{aligned}
\text { Heat loss } & =\text { total } \mathrm{Q} \times 24 \\
& =463.68 \times 24 \\
& =11128.32 \mathrm{Btu} / \text { day } \\
& =11128.32 \times 1.055 \\
& =11740.38 \mathrm{~kJ} / \mathrm{hr}
\end{aligned}
$$

2) Temperature after 24 hours

$$
\begin{array}{ll}
\mathrm{Q} & =\mathrm{m} \times \mathrm{c} \times \Delta \mathrm{T} \\
\mathrm{m} & =3409 \mathrm{~kg} / \mathrm{day} \\
\mathrm{c} & =4.2 \mathrm{~kJ} / \mathrm{kg} \mathrm{C} \\
& =\mathrm{Q} /(\mathrm{m} \mathrm{x} \mathrm{c}) \\
\Delta \mathrm{T} & =11740.38 /(3409 \times 4.2)=2.84
\end{array}
$$

$\mathrm{C}$ Initial temperature $=66 \mathrm{C}$

$\Delta \mathrm{T}=$ Initial temperature - Final temperature

$2.84=66-$ Final temperature

Final temperature $=66-2.84=63.16 \mathrm{C}$

\section{Pipe Insulation}

To find out the amount of heat loss in the pipe can be calculated using the equation written by Z. K. Moray, D. D Gvozdenac in the Applied Industrial Energy and Environmental Management.

1) Required data:

- Outside insulation diameter $(\mathrm{D} 3)=50 \mathrm{~mm}$

- Pipe outside diameter $(\mathrm{D} 2)=25 \mathrm{~A}=0.034 \mathrm{~m}$

- Pipe material = copper

- Insulation material = glasswool

- Thermal insulation conductivity $(\mathrm{kin})=0.05 \mathrm{~W} /$ $\mathrm{m} \mathrm{C}$

- Insulation heat transfer coefficient (hout) $=6.5 \mathrm{~W}$ / $\mathrm{m} 2 \mathrm{C}$

- The temperature of fluid in the pipe $($ Tin $)=660 \mathrm{C}$

- Ambient temperature (Tout) $=250 \mathrm{C}$

2) The overall heat transfer coefficient

$$
\begin{aligned}
\mathrm{U} & =\frac{\frac{1}{D 3 \ln \left(\frac{D 3}{D 2}\right)}}{2 . k \text { in }}+\frac{1}{\text { hout }} \\
= & \frac{\frac{1}{0.05 \ln \left(\frac{0.05}{0.034}\right)}}{2.0 .05}+\frac{1}{6.5}=5.31 \mathrm{~W} / \mathrm{m}^{2} \mathrm{C}
\end{aligned}
$$

3) Heat loss per one meter of insulated pipe $\mathrm{Q} / \mathrm{L}=\pi$.D3.U (Tin - Tout)

$$
\begin{aligned}
& =3.14 \times 0.05 \times 5.31(66-25) \\
& =34.18 \mathrm{~W} \\
& =123048 \mathrm{~J} / \mathrm{hr}
\end{aligned}
$$

4) Heat loss (24 hours)

$$
\begin{aligned}
\text { Heat loss } & =\mathrm{Q} / \mathrm{L} \times 24 \text { hours } \\
& =123048 \times 24 \\
& =2953152 \mathrm{~J} \\
& =2953.15 \mathrm{~kJ}
\end{aligned}
$$

5) Temperature after 24 hours

$$
\begin{aligned}
& \mathrm{Q} \quad=\mathrm{m} \times \mathrm{c} \times \Delta \mathrm{T} \\
& \mathrm{m}=3409 \mathrm{~kg} / \mathrm{day} \\
& \mathrm{c}=4.2 \mathrm{~kJ} / \mathrm{kg} \mathrm{C}
\end{aligned}
$$$$
\Delta \mathrm{T}=\mathrm{Q} /(\mathrm{m} \times \mathrm{c})
$$

$$
=2953.15 /(3409 \times 4.2)=0.86^{0} \mathrm{C}
$$

Initial temperature $=66 \mathrm{C}$

$\begin{array}{ll}\Delta \mathrm{T} & =\text { Initial temperature }- \text { Final temperature } \\ 0.86 & =66-\text { Final temperature }\end{array}$

Final temperature $=66-0.86=65.14 \mathrm{C}$

\section{E. Cost Analysist}

From the previous calculations obtained the heat requirements needed to heat water from a temperature of $250 \mathrm{C}-660 \mathrm{C}$ which is equal to $587029.8 \mathrm{~kJ} /$ day. With a heat of $587029.8 \mathrm{~kJ} /$ day, it can be converted into $\mathrm{kWh}$, where $1 \mathrm{kWh}$ is equal to $1 \mathrm{~kJ} / \mathrm{s}$ so that the value is $167.12 \mathrm{kWh}$. of these values can be calculated the costs required.

$$
\begin{aligned}
\text { Heat needed } & =587029.8 \mathrm{~kJ} / \text { day } \\
& =167.12 \mathrm{kWh}
\end{aligned}
$$

Price of Electricity Industry per kWh = Rp. 1467.28

$$
\begin{aligned}
& \text { Usage Operating Costs }=\text { Rp. } 245,211,833 \text { per day } \\
& =\text { Rp. } 7,356,355,008 \text { per month } \\
& =\text { Rp. } 88,276,260,096 \text { per year }
\end{aligned}
$$

Based on the calculations above it can be concluded that by utilizing waste heat as a substitute for electric water heater can minimize costs of Rp. 245,211,833 per day or Rp. 7,356,355,008 per month.

\section{CONCLUSION}

Based on the results of calculations from data analysis in utilizing waste heat like a heater (water heater) for domestic systems, it can be summarized as follows:

1) Fresh water needed for the supply of hot water in the domestic system is $3409 \mathrm{Kg}$ /day and requires heat of $167.12 \mathrm{~kJ} / \mathrm{s}$ to increase the temperature from $25^{0} \mathrm{C}$ to $66^{\circ} \mathrm{C}$.

2) From the calculation results, the heat output from the exhaust gas is $469 \mathrm{~kJ} / \mathrm{s}$ when the engine loads $50 \%$, $645 \mathrm{~kJ} / \mathrm{s}$ when the engine loads $75 \%, 729 \mathrm{~kJ} / \mathrm{s}$ when the engine loads $80 \%$ and $781 \mathrm{~kJ} / \mathrm{s}$ from the $100 \%$ load engine. While the heat generated in cooling water (HT) is $252 \mathrm{~kJ} / \mathrm{s}$.

3) From the calculation results that have been planned, the heat exchanger used is shell and tube type with the following specifications Shell outer diameter 15.25 in, number of baffle 4 , number of pass on shell side 1, while inner diameter on tube side 1 in, number of pass on tube side 2 , distance between tubes $1.25 \mathrm{in}$, length of tube $8 \mathrm{ft}$, number of tubes 68 , and distance between baffles $3.05 \mathrm{in}$.

4) Tank insulation thickness of $0.2 \mathrm{ft}$ or $610 \mathrm{~mm}$ using glass wool material, within 24 hours the temperature of fresh water drops to $63.16^{\circ} \mathrm{C}$. While the insulation of the pipe is $50 \mathrm{~mm}$ with glass wool material, the temperature in 24 hours drops from 66 to $65.14^{0} \mathrm{C}$.

5) By utilizing waste heat as a substitute for an electric water heater for domestic needs on a 48-meter cruise ship, it can minimize the expenditure of $\mathrm{Rp}$. 
$245,211,833$ per day or Rp. 7,356,355,008 per month.

\section{REFFERENCES}

[1] Santoso, Daniel.,"Pemanfaatan panas buang pengkondisian udara sebagai pemanas air dengan menggunakan penukar panas helikal". Majalah Buritan (Surabaya). 2017. 22 Mei.

[2] Rahardjo, Samsul.,'Peluang pemanfaatan panas gas buang mesin diesel untuk memanasi air".

[3] Priyadi, Agung.,(2011)" Pemanfaatan panas gas buang motor diesel 7 PK sebagai pemanas air".

[4] Rahman, M. M., and Ng, Adrian., (2007), "Air Conditioning and Water Heating-An Environmental Friendly Cost Effective Way of Waste Heat Recovery", Jurnal Engineering Education, vol.31.

[5] Cengel, Y.A., (2004), "Heat Transfer A Practical Approach", $2^{\text {nd }}$ Edition in SI Units, Mc Graw Hill Book, Singapore.

[6] Kern, D.Q.,(1950),'Proces Heat Transfer", Mc Graw Hill Book Co.

[7] Jasfi. E, Holman. J.P., (1993),’Perpindahan Kalor, Edidi Keenam, Erlangga, Jakarta.

[8] Reynolds, William C., Perkins, Henry C., (1982). "Termodinamika Teknik edisi kedua". Penerbit Erlangga, Jakarta.

[9] Cengel, Yunus A., Boles Michael A., (1998). "Thermodynamics an engineering approach", WCB/McGraw-Hill, Inc., United States of America.

[10] Kreith, F dan Prijono, A., (1997), "Prinsip - prinsip Perpindahan Panas", Edisi Ketiga, Penerbit Erlangga, Jakarta.

[11] Kakac Sadik, Liu Hongtan, and Pramuanjaroekij Anchasa.,(2012) "Heat Exchanger”, CRC Press, Boca Raton, London.

[12] Kuppan, T., (2000), "Heat Exchanger Design Handbook", Eastern Hampshire Distribution, United States of America.

[13] Shah, R.K., (1990), "Classification of Heat Exchangers", Gupta, J. P., (1986), "Fundamentals of Heat Exchanger and Pressure Vessel" Technology, Hampshire, Washington D.C.

[14] Larowski, A., Taylor, M, A., (1982), "Systematics Procedures for Selection of Heat Exchanger", London.

[15] Sitompul, T.M., (1993), "Alat Penukar Kalor”, PT. Karsa Bayu Bangun, Perkasa Raja Grafika Persada, Jakarta. 